\title{
PERLINDUNGAN HAK KEKAYAAN INTELEKTUAL DALAM UPAYA PENINGKATAN PEMBANGUNAN EKONOMI DI ERA PASAR BEBAS ASEAN
}

\author{
Sigit Nugroho \\ Fakultas Hukum Universitas Bangka Belitung
}

\begin{abstract}
Indonesia in facing free market ASEAN need preparation real, one of them in development regime intellectual wealth equity which can fulfill interests local community.The intellectual wealth right is fundamental economy a nation. The intellectual wealth right is asset for economic growth based science in the era of free market ASEAN. Many obstacles who met in penerpan the intellectual wealth right in indonesia caused because of differences people characteristics premises with regime intellectual wealth equity which exist. Need of the improvements done by government and the stakeholders of forming in order system intellectual wealth equity which according to culture indonesian people to push economic development in the era of free market ASEAN based intellectual wealth.
\end{abstract}

Key words: protection, the intellectual wealth right, economy

\begin{abstract}
ABSTRAK
Indonesia dalam menghadapi pasar bebas ASEAN membutuhkan persiapan yang nyata, salah satunya dalam pembangunan rezim Hak Kekayaan Intelektual yang dapat memenuhi kepentingan masyarakat lokal. Hak Kekayaan Intelektual merupakan fundamental perekonomian suatu bangsa. Hak Kekayaan Intelektual merupakan asset untuk pertumbuhan ekonomi yang berbasis ilmu pengetahuan di era pasar bebas ASEAN mendatang. Banyak hambatan yang ditemui dalam penerpan Hak Kekayaan Intelektual di Indonesia yang disebabkan karena perbedaan karakteristik masyarakat lokal dengan rezim Hak Kekayaan Intelektual yang ada. Perlu adanya pembenahan yang dilakukan oleh pemerintah dan para pemangku kepentingan dalam rangka membentuk sistem Hak Kekayaan Intelektual yang sesuai dengan budaya masyarakat Indonesia untuk mendorong pembangunan ekonomi di era pasar bebas ASEAN yang berbasis kekayaan intelektual.
\end{abstract}

Kata kunci: Perlindungan, Hak Kekayaan Intelektual, Ekonomi

\section{PENDAHULUAN}

\begin{abstract}
Menyambut Masyarakat Ekonomi ASEAN (MEA) perlu ada persiapan yang matang dari negara Indonesia. Dilihat dari dunia usaha, persaingan sehat adalah syarat utama dalam
\end{abstract}

memasuki MEA 2015. Persaingan sehat harus diciptakan dan dikawal dengan ketat agar tidak merugikan dunia usaha di Indonesia. Salah satu lembaga yang terus gencar mengawasi

Sigit Nugroho, Perlindungan Hak Kekayaan Intelektual Dalam Upaya Peningkatan Pembangunan Ekonomi Di Era Pasar Bebas Asean 
persaingan usaha di Indonesia adalah KPPU. Melalui KPPU diharapkan pengawasan dunia usaha dapat berjalan dengan baik.

Memasuki Masyarakat Ekonomi ASEAN, para pengusaha akan mengalami persaingan usaha yang semakin komplek dalam dunia usaha, sehingga dimungkinkan akan terjadi persaingan usaha yang tidak sehat yang terjadi antar pengusaha lokal maupun asing. Kesadaran tentang pentingnya memperhatikan kesiapan MEA 2015 adalah kewajiban utama, karena jika tidak diantisipasi dan tidak dipersiapkan, maka MEA 2015 berpotensi menciptakan instabilitas terhadap perekonomian nasional, bahkan dapat merupakan ajang pencaplokan aset-aset ekonomi penting milik negara. ${ }^{1}$

Persaingan usaha tidak
sehat merupakan suatu
persaingan antar pelaku usaha
dalam menjalankan kegiatan
produksi dan atau pemasaran
barang atau jasa yang dilakukan
dengan cara-cara yang tidak jujur
atau dengan cara melawan
hukum atau menghambat
persaingan usaha.2 Setiap pelaku
usaha hendaknya berada dalam
kondisi persaingan usaha yang

1 Otjih $\begin{gathered}\text { Sewandarijatun, } \\ \text { "Siapkah kita Menghadapi }\end{gathered}$
Masyarakat Ekonomi Asean",
http://leuserantara.com/artikel-
siapkah-kita-menghadapi-
masyarakat-ekonomi-asean-mea-
$2015 /$ diakses tanggal 3 Oktober
2014. Munir Fuady, Hukum Anti
2 Mra
Monopoli Menyongsong ER Era
Persaingan Sehat, Bandung: PT Citra
Aditya Bakti, 2003, hlm. 5.

sehat dan wajar, sehingga tidak menimbulkan adanya pemusatan kekuatan ekonomi pada pelaku usaha tertentu, dengan tujuan agar dapat mendorong pertumbuhan dan bekerjanya ekonomi pasar secara wajar. ${ }^{3}$

Indonesia, sebagai Negara berkembang memiliki kebijakan strategis dalam rangka perlindungan HKI guna menghadapi persaingan bebas di Negara-negara anggota ASEAN lainya, seperti Malaysia, Singapura, Thailand, Filipina, Brunei Darussalam, Vietnam, Kamboja, Laos, dan Myanmar yang akan menyatu dan berintegrasi dalam satu pasar bersama. Perlindungan HKI sangat dibutuhkan terutama yang terdapat pada produk yang dihasilkan Usaha Kecil dan Menengah (UKM) baik yang dipasarkan di dalam maupun di dalam negeri.

Masyarakat pelaku usaha membutuhkan campur tangan pemerintah melalui undangundang untuk mengatur persaingan usaha yang tidak sehat, agar dalam situasi kompetitif seperti sekarang tidak terjadi aspek-aspek negatif dimana pelaku usaha yang memiliki modal kuat, berpengalaman, terampil dan cepat berkembang, tidak total menguasai pasar yang dapat menghalangi tumbuh dan berkembangnya pelaku usaha kecil untuk maju. ${ }^{4}$ Masyarakat Ekonomi ASEAN (MEA) yang akan

\footnotetext{
Suhasril dan Mohammad Taufik Makarao, Hukum Larangan Praktik Monopoli dan Persaingan Usaha Tidak Sehat di Indonesia, Bogor: Ghalia Indonesia, 2010, hlm. Vii.

${ }^{4}$ Ibid., hlm. viii.
}

Sigit Nugroho, Perlindungan Hak Kekayaan Intelektual Dalam Upaya Peningkatan Pembangunan Ekonomi Di Era Pasar Bebas Asean 
segera berlaku efektif akhir 2015 akan berdampak besar pada pengusaha kecil di Indonesia. Para pengusaha kecil perlu adanya jaminan persaingan usaha yang sehat dalam menjalankan usahanya dan juga terobosan dari pemerintah dalam melindungi para pengusaha kecil dan menengah agar dapat bertahan dalam persaingan usaha dengan para pengusaha asing. Dalam hal ini Indonesia perlu adanya peningkatan ekonomi yang berbasis pengetahuan agar dapat bersaing dengan Negara-negara lain melalui persaingan usaha yang sehat.

Menurut Mudrajad Kuncoro, Guru Besar Fakultas Ekonomika dan Bisnis Universitas Gajah Mada (UGM) bahwa persaingan antarpelaku bisnis, baik dari luar maupun dalam negeri akan semakin ketat pada saat Masyarakat Ekonomi ASEAN (MEA) mulai diberlakukan pada 2015. Hal itu seiring dengan dibukanya kran bisnis usaha dari luar negeri untuk bersaing di Indonesia saat MEA berlangsung. Persaingan usaha akan semakin ketat. Produk dari luar negeri akan bebas bersaing di Indonesia. Menurut beliau, meskipun Indonesia turut serta dalam MEA, seyogianya persaingan produk usaha kecil dan besar tetap harus dijaga agar dapat bersaing secara sehat. 5

Bila dikaitkan dengan isu Hak Kekayaan Intelektual (HKI)

5 Tasrief Tarmizi (Editor), "KPPU Perlu Diperkuat Jelang MEA 2015", http://www.antaranews.com/berita/ 428614/kppu-perlu-diperkuat-jelangmea-2015 diakses tanggal 3 Oktober 2014.

Sigit Nugroho, Perlindungan Hak Kekayaan Intelektual Dalam Upaya Peningkatan Pembangunan Ekonomi Di Era Pasar Bebas Asean pada saat ini maka akan ditemukan sebuah kaitan antara dunia usaha (hukum persaingan usaha) dengan HKI. Dunia usaha dalam perkembangannya tidak terlepas dari Hukum HKI. Dunia usaha membutuhkan perlindungan akan produknya dan apa saja yang berkaitan dengan produknya, misalnya merek dari sebuah produk, desain sebuah produk dan lain sebagainya, yang perlu dilindungi agar tidak dimanfaatkan oleh orang lain demi keuntungannya sendiri dan merugikan pemilik hak tersebut.

Kemajuan ekonomi suatu Negara juga dapat dilihat dari banyaknya perlindungan HKI yang dimilikinya. Implementasi perlindungan HKI di Indonesia banyak menemui kendala yang disebabkan oleh berbedanya karakter budaya masyarakat Indonesia yang bersifat komunal dengan karakter dari rezim HKI yang bersifat individual. Untuk itu perlu adanya perlindungan dan perbaikan dalam rezim HKI yang ada di Indonesia agar sesuai dengan kebutuhan masyakat lokal. Sehingga, apabila rezim HKI yang diterapkan di Indonesia sesuai dengan kebutuhan masyarakat lokal, maka akan dapat meningkatkan pertumbuhan ekonomi yang berbasis ilmu pengetahuan.

Dari uraian di atas terdapat beberapa hal yang perlu dikaji yaitu bagaimana peran Hukum HKI kaitannya dengan Hukum Persaingan Usaha? Apa yang menjadi hambatan dalam penerapan HKI di Indonesia? Bagaimana cara mengatasi hambatan tersebut agar perlindungan HKI dapat menjadi 
jalan untuk peningkatan pembangunan ekonomi di era pasar bebas ASEAN?

\section{PEMBAHASAN}

\section{Peran Hukum HKI kaitannya dengan Hukum Persaingan Usaha}

Hukum dalam bidang kekayaan intelektual ini meliputi hak komunal dan hak personal. Perlindungan yang dilakukan pada kedua hak tersebut masih banyak mengalami kendala. Hal tersebut perlu adanya perhatian yang serius dari pemerintah beserta para pemangku kepentingan dan harus ada solusi nyata yang harus dilakukan untuk menyambut pasar bebas ASEAN ke depan. Perlu adanya terobosan dalam bidang hukum untuk dapat memproteksi perekonomian Indonesia yang salah satunya melalui perlindungan kekayaan intelektual dan persaingan usaha yang sehat. Hukum dalam bidang kekayaan intelektual dengan hukum persaingan usaha ini merupakan komplementer, melengkapi atau saling mengisi.

Perkembangan pasar
bebas tanpa disadari secara
langsung telah memberikan
peluang dan kesempatan bagi
seluruh anggota masyarakat di
dalam maupun di luar negeri.
Peluang itu adalah peluang untuk
berlomba-lomba
memperdagangkan barang dan
jasa yang dihasilkan, melampaui
batas wilayah suatu negara secara
lebih cepat, lebih mudah, dan
dengan harga yang sangat murah.
Sehingga dapat menghasilkan
aktivitas ekonomi dan sosial

masyarakat secara signifikan. ${ }^{6}$ $\mathrm{Hal}$ tersebut dapat dibuktikan dengan banyaknya produk luar negeri yang membanjiri pasar dalam negeri.

HKI merupakan fundamental perekonomian suatu bangsa. ${ }^{7}$ Kemajuan ekonomi suatu bangsa dapat dilihat dari seberapa banyak HKI yang dimiliki oleh bangsa tersebut. Semakin banyak HKI yang dimiliki, semakin cepat pertumbuhan ekonomi yang akan

6 Nobuyuki Yasuda, "How Can law Interact With Society? A Note on Recent Law Revorm Movement in Asia”, dalam Naoyuki Sakumoto, Masayuki Kobayashi, Shinya Imaizumi, Law, development and Socio-Economic Changes in Asia, (Japan: Institute of Developing Economies Japan External Trade Organization, 2003), Hlm. 15, dalam Sudarmanto, KI dan HKI Serta Implementasinya Bagi Indonesia, Jakarta: PT. Elex Media Komputindo, 2012, hlm. 17-18.

7 Andy Noorsaman Someng dalam presentasinya pada seminar Manfaat dan Strategi dalam Penggunaan Sistem Hak Kekayaan Intelektual oleh Dunia Usaha Termasuk Usaha Kecil dan Menengah pada tanggal 24 Juni 2008 di Jakarta dengan judul: Strategi Nasional dalam Pengembangan Sistem Hak Kekayaan Intelektual menyampaikan bahwa maksud utama dari Kebijakan Nasional Kekayaan Intelektual (KNKI) adalah menjadikan kekayaan intelektual sebagai sebuah mesin baru pertumbuhan (new engine of growth) di dalam meningkatkan kesejahteraan ekonomi dan sosial, dalam Ansori Sinungan, Perlindungan Desain Industri: Tantangan dan Hambatan dalam Praktiknya di Indonesia, Cetakan ke-1, , Bandung: Alumni, 2011, hlm. 146.

Sigit Nugroho, Perlindungan Hak Kekayaan Intelektual Dalam Upaya Peningkatan Pembangunan Ekonomi Di Era Pasar Bebas Asean 
dicapai Negara tersebut. 8 HKI yang dimiliki dapat dijadikan tolok ukur dalam melihat kemajuan dan perkembangan perekonomian suatu bangsa. Sehingga dengan semakin banyaknya HKI yang dimiliki suatu bangsa dapat dijadikan sebagai pemacu perkembangan ekonomi dan meningkatkan daya saing produk yang dihasilkan dari dalam negeri tersebut. Menurut Shahid Alikhan, penerapan sistem HKI merupakan batu loncatan dari sistem ekonomi modern di tingkat nasional dan sekaligus merupakan katalisator pembangunan. Dan HKI merupakan asset untuk pertumbuhan ekonomi yang berbasis ilmu pengetahuan ${ }^{9}$ di era pasar bebas ASEAN mendatang.

$\begin{array}{lcr}\text { Peran } & \text { Hak } & \text { Kekayaan } \\ \text { Intelektual } & \text { (HKI) } & \text { dalam } \\ \text { persaingan usaha di } & \text { Indonesia } \\ \text { tidak dapat } & \text { dikesampingkan } \\ \text { begitu saja } & \text { keberadaannya. }\end{array}$
Keberadaan rezim hukum HKI dan Hukum Persaingan Usaha hendaknya dipandang sebagai ketentuan hukum yang bersifat komplementer atau saling mengisi untuk keharmonisan sistem hukum nasional Indonesia. ${ }^{10}$

${ }^{8}$ Ansori Sinungan, Perlindungan Desain Industri: Tantangan dan Hambatan dalam Praktiknya di Indonesia, Cetakan ke-1, Bandung: Alumni, 2011, hlm. 147

9 Ibid., hlm. 148.

10 Peraturan KPPU RI No. 2 Tahun 2009 Tentang Pengecualian Penerapan UU No. 5 Tahun 1999 Tentang Larangan Praktek Monopoli dan Persaingan Usaha Tidak Sehat Terhadap Perjanjian Yang Berkaitan Dengan Hak Atas kekayaan Intelektual, Hlm. 4, dalam Sukarmi, Peran UU Larangan Praktek Monopoli dan Persaingan Usaha Tidak Sehat
Kesamaan yang dimiliki oleh kedua rezim hukum tersebut diantaranya ialah pada tujuannya yaitu untuk memajukan sistem perekonomian nasional di era perdagangan bebas dan globalisasi, mendorong inovasi dan kreatifitas serta untuk meningkatkan kesejahteraan rakyat. ${ }^{11}$

HKI pada umumnya
berhubungan perlindungan penerapan ide dan informasi yang memiliki nilai komersial.12 Secara faktual, HKI merupakan satu sistem pemberian perlindungan hukum bagi karya-karya intelektual yang mencakup jangkauan yang luas, dari pengetahuan tradisional sampai program komputer dan Internet di era bisnis digital saat ini. ${ }^{13}$ HKI merupakan hak untuk menikmati hasil kreativitas intelektual manusia secara ekonomis ${ }^{14}$, karena adanya

dalam Meningkatkan Persaingan Usaha di Era AFTA, dalam Jurnal Persaingan Usaha, Edisi 4, 2010, hlm. 9.

${ }^{11}$ Sukarmi, Peran UU Larangan Praktek Monopoli dan Persaingan Usaha Tidak Sehat dalam Meningkatkan Persaingan Usaha di Era AFTA, dalam Jurnal Persaingan Usaha, Edisi 4, 2010, hlm. 9.

12 Tim Lindsey, dkk. (editor), Hak Kekayaan Intelektual Suatu Pengantar, Bandung: PT. Alumni, 2011, hlm. 3.

13 Abdul Rasyid Saliman, Hukum Bisnis untuk Perusahaan: Teori dan Contoh Kasus, Edisi kedua, Cetakan ke-6, Jakarta: Prenada Media Group, 2011, Hlm. 144.

14 Sudaryat, dkk., Hak Kekayaan Intelektual, Cetakan I, Bandung: Oase Media, 2010, Hlm. 15.

Sigit Nugroho, Perlindungan Hak Kekayaan Intelektual Dalam Upaya Peningkatan Pembangunan Ekonomi Di Era Pasar Bebas Asean 
potensi keuntungan ekonomis. ${ }^{15}$ HKI adalah salah satu alat pemicu untuk mendorong pertumbuhan produk industri, dan secara umum HKI dapat mendorong pertumbuhan ekonomi nasional melalui penciptaan iklim usaha yang sehat. Sehingga kita dapat bersaing dengan produk industri berbasis KI (Kekayaan Intelektual) dan HKI milik negara lain. ${ }^{16}$

Hak kekayaan intelektual mencakup hak komunal eksklusif yang terdiri dari hak ekonomi dan hak moral. Hak ekonomi merupakan hak yang dimiliki oleh seorang inventor dan pendesain untuk mendapatkan keuntungan atas invensi dan karya desain industrinya. Hak ekonomi tersebut berkembang dengan pemanfaatan hak secara komersial. Hal tersebut dapat dijelaskan misalnya sebagai berikut. Hak secara komersial didapat dengan alasan bahwa mewujudkan ide dan gagasan dalam sebuah tulisan, kemudian dilanjutkan dengan sebuah temuan produk di bidang teknologi (paten) maupun karya desain industri, tentu memerlukan pengorbanan waktu, tenaga, dan biaya. Oleh karena itu, hasil suatu temuan karya intelektual harus dapat dikelola secara komersial, agar dapat mengembalikan modal dan memperoleh keuntungan. Hak moral merupakan hak melindungi kepentingan pribadi di Inventor

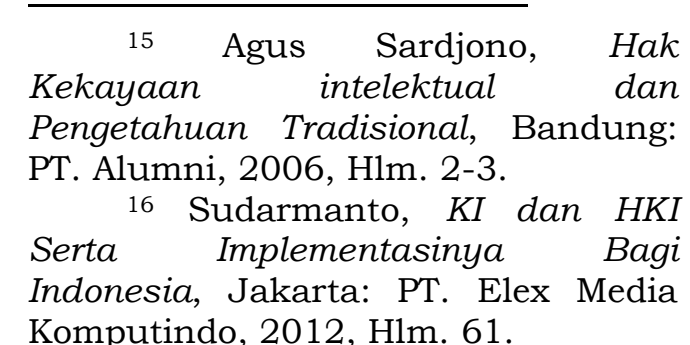

(penemu) dan $\quad$ reputasi
pendesain.17

Berbicara mengenai HKI dan Hukum Persaingan Usaha terdapat dua sisi yang harus dipahami. Pertama, mengenai perlindungan hak intelektual sebagai bentuk insentif dan penghargaan agar memacu kreatifitas dan inovasi dalam mengembangkan seni, ilmu pengetahuan, teknologi dan perdagangan yang diharapkan akan meningkatkan kualitas peradaban masyarakat. 18 Pengaturan mengenai HKI memberikan kesempatan kepada inventor atau pemegang hak untuk dapat mengambil keuntungan dari hasil yang timbul akibat kemampuan intelektual manusia. ${ }^{19}$ Kedua, hukum persaingan usaha berbicara mengenai perlindungan terhadap iklim berkompetisi yang fair guna terbukanya peluang ekonomi, inovasi, dan kesempatan berusaha bagi semua pihak. Pada prinsipnya hukum ini akan memberikan kesempatan untuk kepastian berusaha bagi semua orang dengan cara membebaskan pasar guna efisien dan kompetisi yang fair untuk memberikan konsumen alternatif pilihan yang terbaik dalam pasar. ${ }^{20}$

Kedua hukum tersebut harus saling berkolaborasi dalam meningkatkan perekonomian di Indonesia. Hukum HKI memacu agar kreatifitas dan inovasi masyarakat Indonesia semakin baik. Hukum HKI juga menjaga agar hasil dari kreatifitas dan

\footnotetext{
17 Ibid., Hlm. 1-2.

18 Sukarmi, Op.Cit., Hlm. 9.

19 Sudarmanto, Op.Cit., Hlm. 3.

20 Sukarmi, Op.Cit., hlm. 9.
} 
inovasi tersebut tidak digunakan oleh orang lain yang tidak berhak atas kekayaan intelektual tersebut demi keuntungannya sendiri. Sedangkan Hukum Persaingan Usaha melindungi iklim kompetisi yang fair, sehingga akan memacu para pelaku usaha dalam melakukan kreatifitas dan inovasi dalam mengembangkan produk dalam dunia usaha yang lebih bermutu dan dapat bersaing dengan produk luar negeri.

\section{Indonesia}

dikenal memiliki keragaman hayati yang tinggi, keberagaman budaya dan karya tradisional. Tanpa disadari bahwa banyak aset dan kekayaan intelektual lokal itu telah banyak terdaftar di luar negeri sebagai milik orang asing. Kurangnya kesadaran akan pentingnya aset karya intelektual ini telah mengakibatkan kerugian yang besar bagi Indonesia. ${ }^{21}$ Seperti yang telah diungkapkan oleh Agus Sardjono, bahwa masyarakat sebagai pemilik dari pengetahuan tersebut sama sekali tidak memperhitungkan keuntungan ekonomi dan tidak memiliki keinginan untuk melindungi pengetahuan mereka itu dari pengambilan yang dilakukan orang luar. Hal itu disebabkan oleh adanya anggapan bahwa pengetahuan tersebut adalah milik bersama. ${ }^{22}$ Sehingga perlu adanya perhatian yang serius dalam permasalahan tersebut untuk dapat dicari solusinya.

\footnotetext{
21 Kompas, "Aset Karya Intelektual Banyak Dicuri Pihak Asing", 30 Maret 2000, dalam Adrian Sutedi, Hak Atas Kekayaan Intelektual, Jakarta: Sinar Grafika, 2009, hlm. 6. 22 Agus Sardjono, Op.cit, hlm.
}

11.
Hak Atas Kekayaan Intelektual telah menjadi bagian terpenting suatu negara untuk menjaga keunggulan industri dan perdagangannya. Diakui bahwa pertumbuhan ekonomi suatu negara sangat bergantung kepada sektor perdagangannya, yang pada akhirnya ditentukan pula oleh keunggulan komparatif yang dimilikinya. Keunggulan komparatif sangat bergantung kepada kemampuan teknologinya, salah satu unsurnya adalah pada bidang cakupan kekayaan intelektual.23 Jadi, kekayaan intelaktual menjadi salah satu bagian yang sangat penting dalam pergaulan internasional menjelang pasar bebas ASEAN. HKI menjadi sangat penting untuk menggairahkan laju perekonomian dunia yang pada akhirnya membawa kesejahteraan umat manusia. ${ }^{24}$ Perlu adanya revitalisasi HKI di Indonesia yang dilakukan oleh pemerintah dengan mengeluarkan kebijakan dan terobosan hukum yang dapat membangkitkan kesadaran masyarakat akan HKI dan mengeluarkan kebijakan berupa program "jemput bola" agar masyarakat yang kurang mampu untuk melakukan perlindungan hasil dari kekayaan intelektualnya dapat terlindungi dengan baik dan penegakan Hukum HKI menjadi lebih efektif. Semakin banyaknya kekayaan intelektual masyarakat Indonesia yang terlindungi, maka akan dapat mendorong laju

23 Muhamad Djumhana dan Djubaedillah, Hak Milik Intelektual: Sejarah, Teori dan prakteknya di Indonesia, PT. Bandung: Citra Aditya Bakti, 2003, hlm. 10.

24 Adrian Sutedi, Hak Atas Kekayaan Intelektual, Jakarta: Sinar Grafika, 2009, hlm. 5.

Sigit Nugroho, Perlindungan Hak Kekayaan Intelektual Dalam Upaya Peningkatan Pembangunan Ekonomi Di Era Pasar Bebas Asean 
perekonomian Indonesia di era pasar bebas. Selain itu, perlu dorongan dari iklim persaingan usaha yang sehat yang diciptakan oleh penegakan hukum persaingan usaha yang optimal dan berkeadilan, sehingga perekonomian Indonesia semakin kuat.

\section{Hambatan Penerapan HKI di Indonesia}

Bangsa Indonesia sebagai negara berkembang tidak mudah dalam menerapkan rezim HKI. Sebab, Indonesia mempunyai kekhasan dalam karakteristik masyarakatnya. Masyarakat di Indonesia merupakan masyarakat komunal yang menempatkan kepentingan bersama lebih tinggi dari kepentingan individu, meskipun itu tidak berarti pula bahwa individu kehilangan hakhaknya. ${ }^{25}$ Seperti halnya kebiasaan tolong menolong merupakan salah satu ciri yang menonjol dalam masyarakat lokal seperti di Indonesia. Ciri ini boleh jadi bersumber pada etika kebatinan masyarakat, khususnya masyarakat Jawa, yang antara lain dirumuskan dengan kata-kata sepi ing pamrih, rame ing gawe, mamayu hayuning bawono. ${ }^{26}$ Kata sepi ing pamrih diartikan sebagai tidak mementingkan diri sendiri atau tidak dikendalikan oleh hasrat demi keuntungan pribadi. Kata rame ing gawe diartikan sebagai 132 .

${ }^{25}$ Agus Sardjono, Op.Cit., hlm.

26 Niel Mulder, Mistisisme Jawa: Ideologi di Indonesia, (Yogyakarta: LkiS, 2001), Hlm. 59 dalam Agus Sardjono, Hak Kekayaan intelektual dan Pengetahuan Tradisional, Bandung: PT. Alumni, 2006, hlm. 132.

Sigit Nugroho, Perlindungan Hak Kekayaan Intelektual Dalam Upaya Peningkatan Pembangunan Ekonomi Di Era Pasar Bebas Asean aktif atau bahkan penuh semangat untuk melakukan perbuatan yang baik demi kemaslahatan semua orang. ${ }^{27}$ Sedangkan kata mamayu hayuning bawono diartikan untuk memperindah atau menghiasi dunia. 28

Tujuan kebatinan dari filasafat ini adalah mencapai kesatuan dengan "realitas tertinggi", membangun hubungan yang harmonis dengan Tuhan dengan cara mengatasi diri sendiri. Meskipun jalan menuju pencapaian itu dapat dilakukan dengan langkah-langkah dasar duniawi, seperti menghormati tatanan sosial, tetapi semuanya itu bertujuan melepaskan diri manusia dari segala ikatan duniawi. ${ }^{29}$ Selain itu juga ada sistem tolong menolong dan gotong royong. Konsep gotong royong merupakan suatu konsep yang erat bersangkut paut dengan kehidupan rakyat di dalam masyarakat agraris. ${ }^{30}$ Kebiasaan tolong menolong tampak dalam aktivitas kehidupan masyarakat Indonesia sehari-hari. Beberapa contoh karakteristik masyarakat di atas merupakan karakter 132

27 Agus Sardjono, Op.cit., hlm.

28 Ibid., hlm. 133

29 Niel Mulder, Mistisisme Jawa: Ideologi di Indonesia, (Yogyakarta: LkiS, 2001), Hlm. 59 dalam Agus Sardjono, Hak Kekayaan intelektual dan Pengetahuan Tradisional, Bandung : PT. Alumni, 2006, hlm. 133.

30Koentjaraningrat,

Kebudayaan Mentalitet dan Pembangunan, (Gramedia, 1979), 59, dalam Agus Sardjono, Hak Kekayaan intelektual dan Pengetahuan Tradisional, Bandung: PT. Alumni, 2006, hlm. 135. 
religious dari masyarakat Indonesia.

Bila dikaitkan dengan penerapan HKI di Indonesia. Ciri dari masyarakat Indonesia sangat berbeda dengan isu tentang perlindungan atas kepentingan ekonomi individu pemilik hak dalam sistem HKI. ${ }^{31}$ Masyarakat lokal banyak yang tidak peduli terhadap upaya perlindungan HKI. HKI bersifat individualistik dan masyarakat Indonesia adalah masyarakat komunal yang sangat menghargai kebersamaan. Keduanya saling bertentangan, sehingga penerapan HKI di Indonesia banyak mendapatkan kendala. Konsep HKI yang dibawa di Indonesia kurang pas terhadap budaya yang ada di Indonesia. Hal tersebut menjadi tantangan tersendiri bagi pemerintah untuk membentuk perundang-undangan yang sesuai dengan budaya komunal yang ada di Indonesia.

Hambatan yang dihadapi
dalam penerapan HKI di
Indonesia cukup bervariasi,
tergantung pada jenis
perlindungannya. Rezim HKI tidak
dapat melindungi pengetahuan
tradisional. Seperti yang
diungkapkan oleh Agus Sardjono,
bahwa HKI adalah sebuah rezim
yang sama sekali berbeda dengan
karakteristik dari pengetahuan
tradisional. HKI adalah rezim
individualistik untuk memonopoli
teknologi guna melindungi

31 K.J. Greene, "Copyright, Culture \& Black Music: A Legacy of Unequal Protection", Hastings Communication and Entertainment Law journal, (Vol 21, Winter 1999), 340, dalam Agus Sardjono, Hak Kekayaan intelektual dan Pengetahuan Tradisional, Bandung: PT. Alumni, 2006, hlm. 138. investasi (modal). HKI tidak dapat dilepaskan dari kepentingan pemilik modal. Seperti misalnya teknologi obat-obatan. Karakter HKI yang demikian jelas tidak memungkinkan untuk diaplikasikan pada sistem perlindungan teknologi obatobatan tradisional (traditional medicinal knowledge) yang mempunyai karakter yang sangat berbeda dari teknologi farmasi modern yang dikembangkan kaum kapitalis farmasi dunia. ${ }^{32}$

Indonesia sendiri sudah memiliki rezim perlindungan bagi pengetahuan tradisional yang berbentuk folklore, 33 seperti yang tertuang dalam Pasal 10 UndangUndang Nomor 19 Tahun 2002 tentang Hak Cipta. Akan tetapi, ketentuan pasal tersebut masih sulit untuk diimplementasikan. Salah satu alasannya adalah bahwa pasal tersebut memerlukan peraturan pelaksanaan yang sampai saat ini belum diterbitkan. ${ }^{34} \mathrm{Hal}$ tersebut menunjukkan bahwa salah satu kendala penerapan HKI di Indonesia adalah pada peraturan perundang-undangan yang belum lengkap.

\section{Dalam mendapatkan perlindungan HKI terkadang prosedurnya terlampau rumit. Sebagai contoh prosedur paten.} 148.

32 Agus Sardjono, Op.Cit., hlm.

33 Folklore adalah kreasi yang berorientasi pada kelompok dan berlandasakan tradisi sebagai suatu ekspresi dari budaya dan identitas sosialnya dan pada umumnya disampaikan atu ditularkan secara lisan melalui peniruan atau dengan cara lainnya.

Sigit Nugroho, Perlindungan Hak Kekayaan Intelektual Dalam Upaya Peningkatan Pembangunan Ekonomi Di Era Pasar Bebas Asean 
Masyarakat lokal pada umumnya masih banyak yang tidak memahami bagaimana prosedur atau tahapan yang harus dilalui untuk memperoleh hak paten. Pada Pasal 24 Undang-Undang Nomor 14 Tahun 2001 tentang Paten menjelaskan bahwa permohonan paten diajukan secara tertulis dalam bahasa Indonesia kepada Direktorat Jenderal. Permohonan harus memuat: ${ }^{35}$ (a) tanggal, bulan, dan tahun permohonan, (b) alamat lengkap dan alamat jelas pemohon, (c) nama lengkap dan kewarganegaraan Inventor, (d) nama dan alamat lengkap Kuasa apabila Pemohon diajukan melalui Kuasa, (e) surat kuasa khusus, dalam hal Permohonan diajukan oleh Kuasa, (f) pernyataan permohonan untuk dapat diberi Paten, (g) judul Invensi, (h) klaim yang terkandung dalam Invensi, (i) deskripsi tentang Invensi, yang secara lengkap memuat keterangan tentang cara melaksanakan Invensi, (j) gambar yang disebutkan dalam deskripsi yang diperlukan, (k) untuk memperjelas Invensi, dan (l) abstrak Invensi. Syarat yang tertuang dalam Pasal 24 UndangUndang Paten tersebut tidak mudah dipenuhi oleh masyarakat lokal yang akan melakukan klaim perlindungan bagi pengetahuan obat-obatan tradisional.

Hambatan lain yang berhubungan dengan inventor, seperti misalnya pada paten. Dalam perlindungan paten menuntut tindakan aktif dari inventor untuk mendapatkan perlindungan. Rezim paten

35 F. Agsya Guza (penghimpun), Hak Kekayaan Intelektual, Jakarta: Asa Mandiri, 2011, hlm. 62-63. menuntut masyarakat berlaku aktif mengajukan permintaan perlindungan. Masyarakat lokal yang ingin meminta perlindungan paten harus melakukan berbagai langkah administratif dan sebelumnya mereka harus menyusun dokumen yang berisi spesifikasi paten serta klaim yang dikehendaki. ${ }^{36}$ Masyarakat lokal juga kesulitan dalam pembuatan drafting paten sebagai salah satu sarat formal pengajuan perlindungan paten yang sesuai dengan yang diinginkan oleh Kantor Paten. Hal tersebut menjadi kendala paling nyata dalam mendapatkan perlindungan paten. Tradisi masyarakat lokal pada umumnya yang tidak terbiasa dengan budaya tulisan. Pola-pola perilaku anggota masyarakat tradisional di Indonesia ditentukan oleh normanorma tradisional yang diakui dan dipatuhi yang secara umum dikenal sebagai adat. ${ }^{37}$

Lemahnya dukungan budaya hukum mengakibatkan tidak terpercayainya suatu efektivitas hukum. Hal ini juga menjadi hambatan dalam penerapan HKI di Indonesia. Dalam rangka memperkuat perekonomian domestic dengan orientasi dan berdaya saing global, dilakukan upaya produktivitas nasional melalui 185.

36 Agus Sardjono, Op.cit, hlm.

37 Harsja W. Bachtiar, "The Religion of Java: Sebuah Komentar", Majalah Ilmu-Imu Sastra Indonesia, (Jilid V, No. 1, Januari 1973), dilampirkan dalam Geertz, The Religion of Java, 526, dalam Agus Sardjono, Hak Kekayaan intelektual dan Pengetahuan Tradisional, Bandung: PT. Alumni, 2006, Hlm. 189.

Sigit Nugroho, Perlindungan Hak Kekayaan Intelektual Dalam Upaya Peningkatan Pembangunan Ekonomi Di Era Pasar Bebas Asean 
inovasi, penguasaan penelitian, pengembangan dan penerapan iptek menuju ekonomi berbasis pengetahuan serta kemandirian dan ketahanan bangsa secara berkelanjutan, mengelola kelembagaan ekonomi yang melaksanakan praktik terbaik dan kepemerintahan yang baik secara berkelanjutan, dan mengelola sumber daya alam secara berkelanjutan. ${ }^{38}$ Potensi untuk mengembangkan HKI bertumpu pada sumber daya manusia (SDM) yang memiliki bakat dan keahlian untuk berinovasi. Jika pelaku ekonomi di Indonesia kurang peduli terhadap perlindungan HKI, maka akan sangat mempengaruhi penerapan HKI untuk bisa berjalan dengan baik. Seperti contoh yang penulis kutip dari bukunya Ansori Sinungan, hasil dari penelitin yang dilakukan sejak oktober 2006 sampai Februari 2008 bahwa fakta dilapangan menunjukkan bahwa UKM di Indonesia belum memanfaatkan UU Desain Industri. UKM belum sepenuhnya memanfaatkan perlindungan HKI. ${ }^{39}$ Hal tersebut dapat menjadi salah satu bukti bahwa budaya hukum masyarakat masih kurang dalam bidang HKI.

Faktor penghambat di atas merupakan sebagian dari banyaknya hambatan dalam penerapan HKI di Indonesia. Perlu adanya kebijakan dan terobosan yang dilakukan oleh pemerintah dan perlu adanya dorongan dari berbagai pihak (pemangku kepentingan) untuk dapat bersama-sama meningkatkan

${ }^{38}$ Ansori Sinungan, Op. Cit.,
hlm. 451 . hlm. 453.

39 Ansori Sinungan, Op. Cit., peran HKI dalam membangun perekonomian bangsa Indonesia yang bisa saja akan semakin terpuruk pada saat memasuki era pasar bebas ASEAN apabila bangsa Indonesia tidak siap. Karena dalam pasar bebas ASEAN, Indonesia akan mendapatkan peluang yang positif dan dapat juga mendapat peluang yang negatif dari berlakunya secara efektif pasar bebas ASEAN.

\section{Strategi dan Terobosan Kebijakan dalam HKI}

bidang $\begin{gathered}\text { Perlindungan dalam } \\ \text { kekayaan intelektual }\end{gathered}$ memang sangat penting dan dibutuhkan dalam mem-back up perekonomian Indonesia dalam perdagangan bebas saat ini. Perlu diingat bahwa perlindungan dalam bidang kekayaan intelektual di Indonesia harus meliputi dua hak yaitu hak komunal dan hak personal. Dalam perkembangannya hak personal ini dikelompokkan menjadi dua yaitu hak cipta dan hak kekayaan industri.

Penting $\begin{array}{r}\text { mengenal } \\ \text { dimiliki }\end{array}$
karakteristik yang hasing-masing hak tersebut yaitu
masing
hak komunal dan hak personal.
Dengan mengenal karakteristik
dua hak tersebut maka dapat
ditentukan bentuk perlindungan
yang cocok bagi masing-masing
hak tersebut.
\begin{tabular}{lcr}
\multicolumn{2}{c}{ Perlindungan } & terhadap \\
kekayaan & intelektual & harus \\
dilakukan & sebagai & upaya \\
membangun & \multicolumn{2}{c}{ perekonomian }
\end{tabular} Indonesia. Menurut penulis, ada beberapa hal yang dapat dilakukan untuk dapat melindungi kekayaan intelektual di Indonesia. Pertama, perlu

Sigit Nugroho, Perlindungan Hak Kekayaan Intelektual Dalam Upaya Peningkatan Pembangunan Ekonomi Di Era Pasar Bebas Asean 
dibentuk perundang-undangan yang sesuai dengan kebutuhan masyarakat lokal. Kedua, Harus dilaksanakan pendokumentasian terhadap kekayaan intelektual Indonesia. Ketiga, peran aktif dan komitmen dari para pemangku kepentingan untuk melindungi kekayaan intelektual Indonesia. Keempat, perbaikan dalam kelembagaan. Kelima, membangun budaya hukum bagi masyarakat.

\section{Perundang-undangan}

sebagai salah satu perangkat yang dapat digunakan dalam melindungi hak-hak warga masyarakat. Gagasan pembentukan perundangundangan yang mengatur mengenai kekayaan intelektual harus dibuat sesuai dengan kondisi dan kebutuhan masyarakat lokal. Mengingat bahwa budaya masyarakat Indonesia berbeda dengan budaya luar. Perlu adanya perundangundangan yang dapat mengakomodir berbagai kepentingan masyarakat lokal. Bila perlu adanya amandemen guna menyesuaikan rezim HKI dengan tuntutan global dan sekaligus aspirasi dan pandangan warga masyarakat Indonesia. Seperti yang telah diungkapkan oleh Agus Sardjono, bahwa pemerintah dapat mempertimbangkan penyusunan perundang-undangan sui generis yang didalamnya mengatur mengenai masalah akses orang asing terhadap sumber daya hayati dan pengetahuan tradisional yang terkait, serta pembagian manfaat yang terjadi karena akses tersebut. ${ }^{40}$ Aspek budaya yang masuk dalam hak kekayaan komunal milik masyarakat tradisional perlu juga diakomodir dalam perundangundangan.

\section{Pendokumentasian}

terhadap kekayaan intelektual Indonesia harus segera dilakukan. Tujuannya adalah untuk mengklime jenis-jenis hak komunal disetiap daerah, menangkal pendaftaran hak komunal yang dilakukan oleh orang asing, dan menyebarluaskan kemanfaatan hak komunal kepada masyarakat Indonesia. ${ }^{41}$ Dalam pelaksanaan pendokumentasian ini bukan berarti tidak mengalami kendala. Akan tetapi kendala tersebut perlu ada solusi yang nyata yaitu dengan mengajak para stakeholders atau pemangku kepentingan untuk berkomitmen penuh, melakukan digitalisasi data dan membuat akses internet lewat Internet, pemberdayaan dan/atau optimalisasi keberadaan Sentra HKI. ${ }^{42}$

\begin{tabular}{llr}
\multicolumn{1}{r}{ Dalam } & \multicolumn{2}{r}{ menyelesaikan } \\
permasalahan & HKI ini perlu \\
adanya peran & aktif dari para \\
pemangku & \multicolumn{2}{c}{ kepentingan. } \\
Komitmen & bersama para
\end{tabular}
pemangku kepentingan menjadi modal dasar dalam perubahan rezim HKI yang sesuai dengan kondisi di Indonesia. Dalam buku yang ditulis oleh Sudarmanto, beliau membagi para pemangku kepentingan menjadi 4 (empat) yaitu pelaku, pelatih, promotor dan wasit. Keempat kelompok pemangku kepentingan tersebut harus bersinergi dengan baik

113.

41 Sudarmanto, Op. Cit., hlm.

42 Ibid., hlm. 114

Sigit Nugroho, Perlindungan Hak Kekayaan Intelektual Dalam Upaya Peningkatan Pembangunan Ekonomi Di Era Pasar Bebas Asean 
untuk dapat melindungi kekayaan intelektual yang ada di Indonesia. Yang dimaksud dengan pelaku adalah pendesain, penemu, pencipta, pemohon HKI, pengrajin, masyarakat industri, pelaksana HKI, dan lain-lain. Pelatih adalah kementerian, non kementerian, dinas, pemda terkait, perguruan tinggi dan Lembaga Penelitian, konsultan HKI, dan lain sebagainya. Promotor terdiri dari asosiasi (kerajinan, industri dan perdagangan), kadin, pengusaha/inventor, LSM, dan lain sebagainya. Sedangkan wasitnya adalah kantor HKI, pengadilan, mahkamah agung, polisi, dan jaksa. 43

Perbaikan
pemerintah untuk mengatasi
permasalahan atau hambatan
dalam implementasi perlindungan
HKI di Indonesia, ialah dengan
melakukan kajian terhadap
semua unsur dari kelembagaan,
seperti legislatif, eksekutif, dan
yudikatif.44 Berhubungan dengan
kajian terhadap semua unsur dari
kelembagaan, dapat dilakukan
revitalisasi sumber daya manusia,
penguatan kelembagaan, dan
tertib administrasir untuk
peningkatan pelayanan. Salah
satu komponen suksesnya
implementasi perlindungan HKI
tidak terlepas dari peran sumber
daya manusia yang akan
melaksanakan proses
pengadministrasian permohonan pendaftaran HKI pada Ditjen HKI. Perlu adanya peningkatan etos kerja agar dapat lebih produktif dalam memberikan pelayanan kepada masyarakat sesuai dengan

Sigit Nugroho, Perlindungan Hak Kekayaan Intelektual Dalam Upaya Peningkatan Pembangunan

113.

44 Ansori Sinungan, Op. Cit.,

hlm. 494.

prinsip good governance. 45 Dibutuhkan sumber daya manusia yang mempunyai pengetahuan luas terhadap HKI. Selain itu, juga perlu adanya penguatan kelembagaan. Penguatan kelembagaan yang menangani masalah perlindungan HKI dalam arti luas. ${ }^{46}$ Dalam rangka memperkuat kelembagaan Ditjen HKI, upaya-upaya yang dapat dilakukan oleh pemerintah adalah penguatan kelembagaan melalui dana anggaran pendapatan dan belanja negara (APBN), maupun bantuanbantuan internasional. ${ }^{47}$ Dalam arti bahwa perlindungan HKI mencakup kekayan komunal dan personal. Untuk mendukung itu semua perlu adanya sikap dan perilaku siap melayani mulai dari pejabat Negara dari tingkat yang paling bawah sampai pada tingkat yang paling tinggi yaitu tingkat pengambil kebijakan (decision maker) dalam jajaran pemerintahan ${ }^{48}$ demi terciptanya suatu pelayanan publik yang baik dalam suatu Negara.

hukum $\begin{gathered}\text { Membangun bagi } \\ \text { budaya }\end{gathered}$ merupakan salah satu cara untuk dapat memberikan kesadaran bagi masyarakat akan pentingnya HKI di era pasar bebas mendatang. Friedman mengatakan bahwa budaya hukum (legal culture) adalah unsur yang utama dapatnya suatu sistem hukum berjalan. Yang dimaksud dengan budaya hukum adalah persepsi masyarakat terhadap hukum dan sistem hukum, pandangan, nilai,

45 Ibid., hlm. 495.

46 Ibid., hlm. 496.

47 Ibid., hlm. 497

48 Ibid., hlm. 498. 
idea dan pengharapanpengharapan mereka terhadap hukum. ${ }^{49}$ Perlu adanya sosialisasi dalam bidang HKI yang dilakukan secara menyeluruh diberbagai kalangan agar terdapat pemahaman akan HKI dan tidak terjadi kesenjangan pemahaman antara pemerintah dengan masyarakat.

\section{PENUTUP}

Hukum HKI dengan Hukum Persaingan Usaha saling berkaitan, saling melengkapi satu sama lain. Iklim persaingan usaha yang sehat dan didukung oleh perlindungan Hak atas Kekayaan Intelektual dalam dunia usaha akan dapat meningkatkan pembangunan ekonomi Indonesia sebagai negara berkembang ke depannya. Semakin banyak HKI dalam negeri yang dimiliki oleh Indonesia maka akan sangat mendukung potensi peningkatan dunia usaha yang lebih baik dalam persaingannya di era pasar bebas ASEAN. Produk dalam negeri akan dapat bersaing dengan produk luar, sehingga akan tercipta kesejahteraan bagi masyarakat lokal.

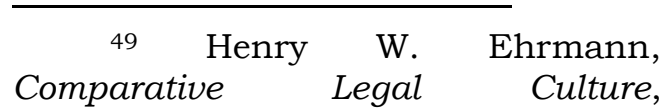
(Englewood Clif, N. J: Prentice Hall, Inc 1976) hlm. 9. Lawrence $M$. Friedman, American Law. (New York: W. W. Norton \& Company:1984), hlm. 6-7, 218-224, Erman Rajagukguk, Nyanyian Sunyi Kemerdekaan Menuju Indonesia Negara Hukum Demokratis. (Tetes-tetes Pemikiran 1971-2006), hlm. 213. dalam Ansori Sinungan, Perlindungan Desain Industri: Tantangan dan Hambatan dalam Praktiknya di Indonesia, Cetakan ke1, Bandung: Alumni, 2011, hlm. 500.

Sigit Nugroho, Perlindungan Hak Kekayaan Intelektual Dalam Upaya Peningkatan Pembangunan Ekonomi Di Era Pasar Bebas Asean
Dalam penerapan HKI di Indonesia tentunya tidak berjalan mulus. Hal tersebut disebabkan karena adanya perbedaan karakteristik rezim HKI dengan karakteristik budaya masyarakat lokal. Karakteristik rezim HKI bersifat individualistik sedangkan karakteristik masyarakat lokal bersifat komunal. Hal tersebut membuat HKI mengalami kendalam dalam penerapannya di Indonesia. Akan tetapi, perlu adanya solusi penengah atau perbaikan dalam bidang HKI untuk dapat menjembatani permasalahan tersebut.

Perbaikan-perbaikan pada konsep perlindungan HKI yang ada sekarang perlu dilakukan. Perbaikan tersebut meliputi pembenahan dalam perundangundangan dan terobosan kebijakan yang dapat mengakomodir kepentingan lokal, pendokumentasian terhadap kekayaan intelektual Indonesia, peran aktif dan saling bersinerginya antara pemerintah dan para pemangku kepentingan dalam bidang HKI, perbaikan dalam kelembagaan, membangun budaya hukum bagi masyarakat. Perbaikan tersebut perlu dilakukan dengan komitmen yang kuat untuk memperbaiki segala kelemahan perlindungan HKI yang ada saat ini. 


\section{DAFTAR PUSTAKA}

Abdul Rasyid Saliman, 2011, Hukum Bisnis untuk Perusahaan: Teori dan Contoh Kasus, Jakarta: Prenada Media Group.

Adrian Sutedi, 2009, Hak Atas Kekayaan Intelektual, Jakarta: Sinar Grafika.

Agus Sardjono, 2006, Hak Kekayaan intelektual dan Pengetahuan Tradisional, Bandung: PT. Alumni.

Ansori Sinungan, 2011, Perlindungan Desain Industri: Tantangan dan Hambatan dalam Praktiknya di Indonesia, Bandung: Alumni.

F. Agsya Guza (penghimpun), 2011, Hak Kekayaan Intelektual, Jakarta: Asa Mandiri.

Muhamad Djumhana dan Djubaedillah, 2003, Hak Milik Intelektual: Sejarah, Teori dan prakteknya di Indonesia, PT. Bandung: Citra Aditya Bakti.

Munir Fuady, 2003, Hukum Anti Monopoli Menyongsong Era Persaingan Sehat, Bandung: PT Citra Aditya Bakti.

Otjih Sewandarijatun, "Siapkah kita Menghadapi Masyarakat Ekonomi Asean", http://leuserantara.com/arti kel-siapkah-kitamenghadapi-masyarakatekonomi-asean-mea-2015/ diakses tanggal 3 Oktober 2014.

Sudarmanto, 2012, KI dan HKI Serta Implementasinya Bagi Indonesia, Jakarta: PT. Elex Media Komputindo.

Sudaryat, dkk., 2010, Hak Kekayaan Intelektual, Cetakan I, Bandung: Oase Media.

Suhasril dan Mohammad Taufik Makarao, 2010, Hukum Larangan Praktik Monopoli dan Persaingan Usaha Tidak Sehat di Indonesia, Bogor: Ghalia Indonesia.

Sukarmi, Peran UU Larangan Praktek Monopoli dan Persaingan Usaha Tidak Sehat dalam Meningkatkan Persaingan Usaha di Era AFTA, dalam Jurnal Persaingan Usaha, Edisi 4, 2010.

Tim Lindsey, dkk. (editor), 2011, Hak Kekayaan Intelektual Suatu Pengantar, Bandung: PT. Alumni.

Tasrief Tarmizi (Editor), "KPPU Perlu Diperkuat Jelang MEA 2015,

http://www.antaranews.com /berita/428614/kppu-perludiperkuat-jelang-mea-2015 diakses tanggal 3 Oktober 2014.

Sigit Nugroho, Perlindungan Hak Kekayaan Intelektual Dalam Upaya Peningkatan Pembangunan Ekonomi Di Era Pasar Bebas Asean 